\title{
Etiopathogenesis of equine intrauterine fluid accumulation
}

\author{
Sibel Özgen ${ }^{7}$, H.-A. Schoon ${ }^{2}$, Heike Aupperle ${ }^{2}$, H. Sieme ${ }^{3}$ und E. Klug $^{1}$ \\ Klinik für Pferde, School of Veterinary Medicine Hannover ${ }^{1}$, Institut für Veterinär-Pathologie, University of Leipzig ${ }^{2}$ und Niedersächsisches Landgestüt Celle 3
}

\begin{abstract}
Summary
In order to achieve further information on the etiology and the pathogenesis of intrauterine fluid accumulations in mares eight mares with fluid accumulations and seven mares with no known reproductive pathology were observed throughout an entire estrous cycle. Examinations were performed using palpation and ultrasonography via the rectum. Blood was taken throughout the cycle for $17 \mathrm{~b}$-estradiol and progesterone determination. In addition biopsy samples were obtained from each mare on day 0 (day of ovulation) 5, 10, 13, 16, 19 and 21 postovulation and examined with different histological methods (light microscopy, morphometry, immunohistochemistry: ER, PR, Ki-67 antigen) and enzyme immunoassay $\left(\mathrm{PGF}_{2 \mathrm{a}}\right)$. Uterine swabs for microbiological evaluation were taken before first biopsy. Ultrasonographically detected fluid accumulations were more often in old barren mares than in young mares. In most cases uterine free fluid appeared at the end of the luteal phase and disappeared around ovulation. Maximal volumes of fluid were estimated during early estrus. Histomorphometrical results indicate hypersecretory activity of the endometrial glandular structures. The length of interovulatory interval of IUF-mares (mares with intrauterine fluid accumulation) was reduced. Progesterone concentrations in mares accumulating fluid were significantly lower than in control mares during the entire luteal phase. In both groups the amount of $\mathrm{PGF}_{2 \mathrm{a}}$ in the endometrium at the early stage of diestrus was low. Bacteria were significantly more often cultured from endometrial swab samples taken from mares with detectable uterine fluid than from mares with no fluid indicating "susceptibility" to bacterial contamination of the uterus. Estrogen and progesterone receptor immunoreactivity in IUF-mares was higher than in control mares. The progesterone profile and endometrial PGF $2 \mathrm{a}$ of mares with fluid collections support the hypothesis that the shortened length of interovulatory interval was due to primary luteal insufficiency rather than uterine-induced luteolysis. Probably due to the lacking of luteal progesterone in IUF-mares the progesterone mediated suppression of the steroid receptors is impeded and glandular cell differentiation is affected to secretion.
\end{abstract}

Key words: mare, intrauterine fluid accumulation, endometrium, steroid receptor, progesterone

\section{Beitrag zur Ätiopathogenese der intrauterinen Flüssigkeitsansammlung (IUF, Hydromucometra) beim Pferd}

Mit dem Ziel, weitere Informationen über die Ätiologie und Pathogenese der equinen Hydromucometra zu erhalten, wurden 8 Stuten mit IUF und 7 Stuten ohne erkennbare Uteropathie über einen vollständigen Sexualzyklus klinisch transrektal-palpatorisch und ultrasonografisch untersucht. Blutproben, über den gesamten Zyklus entnommen, dienten zur Bestimmung von 17ß-Östradiol und Progesteron. Zusätzlich wurden an den Zyklustagen (Tag der Ovulation = Tag 0) 5, 10 13,16, 19 und 21 von jeder Stute Endometriumbiopsien entnommen und mittels verschiedener histologischer Methoden (Lichtmikroskopie, Morphometrie, Immunhistochemie zur Bestimmung der Östrogenrezoptoren ER, Progesteronrezeptoren PR und als Proliferationsmarker KI-67 Antigen) und im Enzymimmunoassay (PGF 2 a) untersucht. Vor der ersten Biopsie wurden Zervixtupfer zur mikrobiellen Untersuchung entnommen. Ultrasonographisch erkennbare Flüssigkeitsansammlungen im Uterus wurden häufiger bei alten, güsten Stuten als bei jungen Stuten nachgewiesen. In der weitaus größten Mehrzahl der Fälle waren intrauterine Flüssigkeitsansammlungen zum Ende der Lutealphase vorhanden, die zur Ovulation hin verschwanden. Maximale Flüssigkeitsmengen wurden im frühen Östrus erkannt. Die histomorphometrischen Untersuchungen ergaben eine hypersekretorische Aktivität der glandulären Strukturen des Endometriums. Das interovulatorische Intervall der IUF-Stuten war verkürzt. Der zirkulierende Progesteronspiegel war bei den IUF-Stuten innerhalb der gesamten Lutelphase signifikant niedriger im Vergleich zu den unauffälligen Stuten. In beiden Stutengruppen war in der frühen diöstrischen Phase die endometriale PGF $2 a^{-K o n z e n t r a t i o n ~ h e r a b g e s e t z t . ~ I U F-S t u t e n ~ w i e s e n ~ h a ̈ u f i-~}$ ger bakteriellen Keimgehalt auf, als die endometrial unauffälligen Stuten, woraus sich auf eine höhere Empfänglichkeit der IUF-Stuten für eine bakterielle Besiedlung schließen lässt. Die Immunreaktivität der Östrogen- und Progesteronrezeptoren waren bei den IUF-Stuten höher als bei den Kontrollen. Das Progesteronprofil und die endometriale PGF 2 -Konzentration bei den IUF-Stuten unterstützt die Hypothese, dass die reduzierte Länge des interovulatorischen Intervalls auf eine primäre luteale Insuffizienz und nicht auf eine uterininduzierte Luteolyse zurückzuführen ist. Es ist wahrscheinlich, dass der Mangel an lutealem Progesteron bei den IUF-Stuten eine Depression der Sexualsteroidrezeptoren erschwert und die glanduläre Zelldifferenzierung in Richtung Sekretion drängt.

Schlüsselwörter: Stute, intrauterine Flüssigkeitsansammlung, Endometrium, Hydromucometra, Steroid-Rezeptor, Ki67-Antigen, Progesteron

\section{Introduction}

The presence of uterine fluid detected with ultrasonography during estrus (Pycock and Newcombe 1996, Squires 1993) and diestrus (Adams et al. 1987, Ginther et al. 1985, McKinnon et al. 1987, 1988, Newcombe 1997, Squires 1993) has been proved that it reduces fertility of mares. uring estrus, uterine fluid may be spermicidal (Katila et al. 1997, Squires et al. 1989) or may represent media ideal to support bacterial proliferation after breeding (McKinnon et al. 1987, Squires et al. 1989); when present during diestrus, it may cause premature luteolysis or embryonic death (Adams et al. 1987, McKinnon 
et al. 1987, Squires et al. 1989). Mares that accumulate fluid in estrus are considered to be susceptible to endometritis (Allen and Pycock 1988). It is presumed that the fluid originates from the excess and watery endometrial gland secretion (Katila et al. 1997, Kropp 1996, Liu 1992, Rasch 1994).

An uterus that tilts ventrally in relation to the pelvic brim may contribute to the inability of delay in uterine clearance mares to rapidly clear their uterine lumen of contamination (LeBlanc et al. 1989, 1998).

The reasons mares susceptible to endometritis experience decreased uterine contractions and a delay in uterine clearance are not known. Abnormalities in myometrial electrical pattern. exhaustion of the uterine smooth muscle (Troedsson and Liv 1991, Troedsson et al. 1993), inappropriate hormonal signals controlling uterine contractions, and abnormal perineal and reproductive conformation have been implicated.

The objective of this study was to determine if the hormonal and endometrial situatin in IUF-mares is different from normal mares.

\section{Materials and Methods}

Fifteen Hannoverian brood mares were used in this study. Eight mares with uterine fluid accumulation (IUF) and seven mares without any apparent uterine abnormalities were observed throughout an entire estrous cycle. The age of the mares ranged from 5 to 18 years and the examinations took place between June and September 1996. No treatment was given to the mares.

\section{Gynecological examination and Ultrasonography}

All mares were examined daily by rectal palpation, transrectal ultrasonography with a $5 \mathrm{MHz}$ transducer and vaginal examination (six times/cycle). The presence and size of all follicles and all luteal structures were recorded. Ovulation was diagnosed by the disappearance of the follicle and the presence of an early corpus luteum as determined by both palpation and ultrasonic imaging. The amount of ultrasonographically detectable fluid within the uterine body or horns was recorded with the formula that is used for the calculation of an ellipse: $(S=$ pab).

\section{Microbiology}

Endometrial swab samples for microbiological evaluation were taken at the beginning of the estrous period. Guarded swabs were used and the sampling was carried out as described by Merkt et al. (1980).

Blood samples

During diestrus, blood samples were taken from the mares every two to three days and during estrus every day in order to determine estradiol-17b and progesterone plasma concentrations by RIA as recommended by Behrens et al. (1993). Enzyme immunoassay
Prostaglandin F2a-concentrations were evaluated in frozen endometrial tissues (CAYMAN CHEMICAL Enzyme Immunoassay Kit).

Histopathology Morphometry and Immunohistochemistry

In addition, endometrial biopsies were obtained during six defined phases of the cycle (day 0, 5, 10, 13, 16, 19, 21). Biopsy specimens were fixed in $4 \%$ buffered formalin, embedded in paraffin and stained with hematoxylin and eosin. The biopsies were evaluated histopathologically according to Kenney and Doig (1986), and endometrial structures, such as glandular diameters and glandular luminal diameters, were measured morphometrically with picture analyzing system Quantimet 500+.

Receptors for estrogen (ER) and progesterone (PR) were stained with the peroxidase anti-peroxidase-technique to determine the receptor expression in epithelial and stromal cells during the different phases of the cycle. The monoclonal antibody $\mathrm{Ki}-67$ was used to examine proliferative activity of endometrial cells. Paraffin embedded tissues were cut and placed on superfrost ${ }^{O}$ slides. Slides were deparaffinized and endogenous peroxidase was inactivated with $\mathrm{H}_{2} \mathrm{O}_{2}$. The primary antibodies (mouse anti-human estrogen receptor, mouse anti-human progesterone receptor and mouse anti-human $\mathrm{Ki}-67$ antigen) were incubated overnight at $4^{\circ} \mathrm{C}$. The second antibody (rat anti-mouse lgG) was applied for 30 minutes followed by the peroxidase anti-peroxidase complex, both incubated at room temperature. Finally the slides were developed in diaminobenzidine and counterstained with PAPANICOLAOUNs fluid.

The evaluations of steroid receptors were recorded as percentage of positive-stained cells in each of four intensity categories. A value was derived consisting of a sum of these percentages multiplied by a weighted intensity of staining.

The immunohistologic reaction was given an Immunoreactive Score, calculated with the following formula:

$$
I R S=\frac{1}{100} \sum_{n=2}^{4}\left\{P P_{n} \times \max \left[\varphi \times\left(S I_{n}-1\right), 1\right]\right\}
$$

$$
\begin{array}{ll}
\text { index } & \mathrm{n} \\
\text { weight } & \varphi=5 \\
\text { percentage of positive cells } & \mathrm{PP} \\
\text { staining intensity } & \mathrm{SI}
\end{array}
$$

Assignment of staining intensity and SI-value
\begin{tabular}{|c|c|c|}
\hline index $n$ & SI & value \\
\hline 1 & absent & 0 \\
2 & weak & 1 \\
3 & moderate & 2 \\
4 & strong & 3 \\
\hline
\end{tabular}

The expression of Ki-67 antigen was quantified by estimation of positively labeled cells and classified as weak (Ki-67 positive cells scarcely detectable, value 1), moderate (several Ki67 positive cells, value 2) and strong (many Ki-67 positive cells, value 3). 
Statistical Analysis

The study involved both categorical data and non-categorical data. Pairwise comparison were made among the groups using student't t-test for categorical data and Mann-Whitney's U-test for non-categorical data. Correlation between hormone plasma concentrations and immunohistochemical markers were calculated with Spearman correlation coefficient. Chi-square analyses were used to compare the incidences of anamnestic, clinical, ultrasonographical and pathohistological findings. A probability level of $P<0.05$ was considered statistically significant.

\section{Results}

Anamnestic evaluations, Gynecological examination and Ultrasonography

Ultrasonographically detected fluid accumulations were more often in old barren mares than in young mares. Daily examinations using transrectal ultrasonography showed that in most cases uterine free fluid appeared at the end of the luteal phase and disappeared around ovulation. Maximum fluid accumulations were measured two days before ovulation. Mares that accumulated fluid, exhibited shorter interovulatory intervals (mean $\pm \mathrm{SD})(\mathrm{x}=18.25 \pm 3.11)$ compared to the control group $(x=20.71 \pm 1.98)(P=0.044)$. The degree of IUF and the length of estrous cycle correlated inversely $(r=-0.716, P=0.046)$.

\section{Microbiology}

Bacteria were significantly $(p<0.001)$ more common cultured from endometrial swab samples of IUF mares. Endometrial swabs of 1 mare (Pseudomonas sp.) of the control group (14\%) and of 4 mares (b-hemolytic streptococcae) of the IUFgroup (50 \%) were classified as bacteriologically positive.

\section{Blood samples}

The cyclic progestin pattern of all mares in this study was similar. During estrus plasma concentrations were below 0.4 $\mathrm{ng} / \mathrm{ml}$. Immediately after ovulation, concentrations increased



Fig 1. Progesterone plasma concentrations in mares with intrauterine fluid accumulation and control mares during the estrous cycle; values are means $\pm \mathrm{SD}$. Levels of significance: ${ }^{*}=\mathrm{p} £ 0.05 ;{ }^{* *}=$ $p £ 0.01 ;^{* * *}=p £ 0.001$ and reached peak diestrus values 5 days after ovulation. Plasma progesterone concentrations showed statistically significant differences during diestrus between the groups. Progesterone plasma values obtained on days 3,5 and 8 of the estrous cycle did not exceed 1.18, 2.29 and $1.76 \mathrm{ng} / \mathrm{ml}$ in the IUF group compared to $3.8,5.83$ and $5.07 \mathrm{ng} / \mathrm{ml}$ in the control group and differed significantly $(p<0.05, p<0.01$, $p<0.01$ ) between the groups. In addition progesterone values in mares accumulating fluid declined earlier in the cycle and ovulation occurred at a shorter interval.

During diestrus baseline levels of estradiol-17b were measured. During proestrus values rose and reached their peak 2 days before ovulation. Estradiol-17b concentration was higher in the control group during the complete cycle, but differed significantly just in later state of diestrus ( $P=0.038)$.

Investigations of endometrial tissues for PGF2a concentrations showed higher values in the IUF group during late diestrus compared to the control group $(P=0.023)$. In early diestrus the values were low in both groups.

\section{Histopathology}

Pathohistologic evaluations of formalin fixed and paraffin embedded biopsies showed no signs of acute endometritis. There was no difference between the group concerning the incidence of chronic inflammatory endometrial changes ( $P=$ 0.389), angiopathies $(P=0.131)$ or lymphangiectasia $(P=0.795)$, but periglandular fibrotic changes were significantly more common in the IUF-group ( $P<0.001)$.

\section{Immunohistochemistry}

Immunohistologic evaluations of estrogen receptors in endometrial samples resulted in different patterns of distribution for epithelial and stromal cells throughout the estrous cycle. Peak immunoreactivity of glandular epithelium was reached in early diestrus. Then the intensity of reaction declined until proestrus and then rose again slowly in early estrus. In contrast to epithelial reaction, ER in stromal cells could scarcely be detected during the luteal phase. Immunoreactivity of stromal cells became more intense at proestrus and stayed high until the end of estrus.

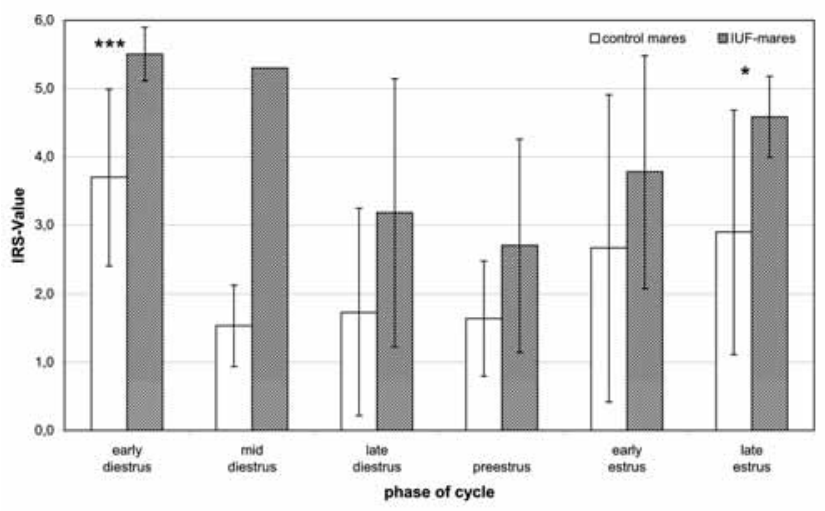

Fig 2 expression of estrogen receptors in apical and mid glands in the endometrium of mares with intrauterine fluid accumulation and control mares during the estrous cycle; values are means \pm SD. Levels of significance: ${ }^{*}=p £ 0.05 ;^{* *}=p £ 0.01 ;^{* * *}=p £$ 
ER immunoreactivity in glandular epithelia of mares with uterine fluid accumulation was greater during all phases of estrous cycle compared to control group. During early diestrus ( $p=0.002$ ) IRS values were significantly higher in the IUF-group compared to control group. Stromal cells also tended to show higher immunoreactivity in the IUF group (statistically significant during early estrus, $P=0.043$ ). PR showed a similar dynamic of activity compared to ER during the cycle. In glandular epithelial cells immunoreactivity of PR was higher in the IUF group. Immunoreactive Scores differed significantly during late estrus ( $d$ ) $(p=0.028)$. PR expression in stromal cells was not different between the groups.

Peak cell proliferation of glandular epithelium was reached in early diestrus. There was no difference between the groups. Ki-67 antigen expression in stromal cells was marked throughout the estrous phase of the cycle. Proliferation was more distinct in IUF-group in proestrus $(P=0.04)$. There is a strong

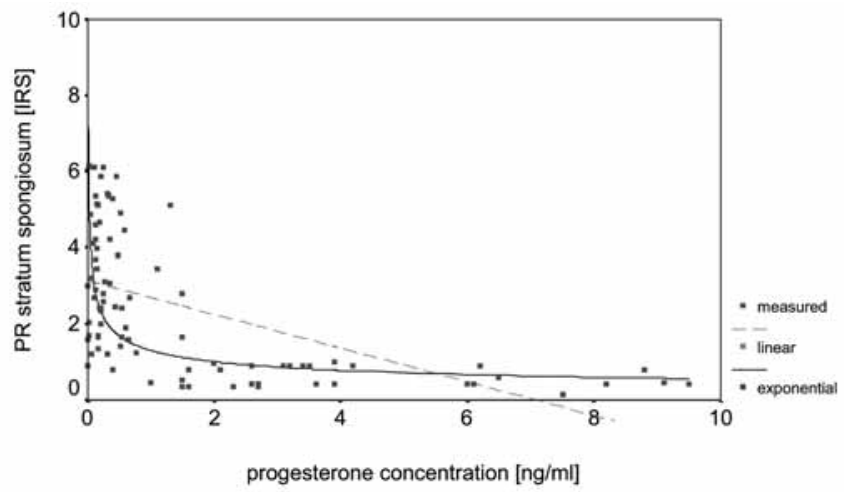

Fig 3 Scatchard plot analysis of progesterone plasma dependent stromal progesterone receptor expression in endometria of both groups

but not linear correlation between progesterone plasma concentration and ER, PR and Ki-67 levels. As progesterone concentration exceeds $1.5 \mathrm{ng} / \mathrm{ml}$ steroid hormone receptor expression and proliferative activity in stromal cells is minimal. On the other hand there is no correlation between plasma progesterone levels and immunohistochemical markers in glandular epithelia, or plasma estradiol levels and immunohistochemical markers in epithelial or stromal cells.

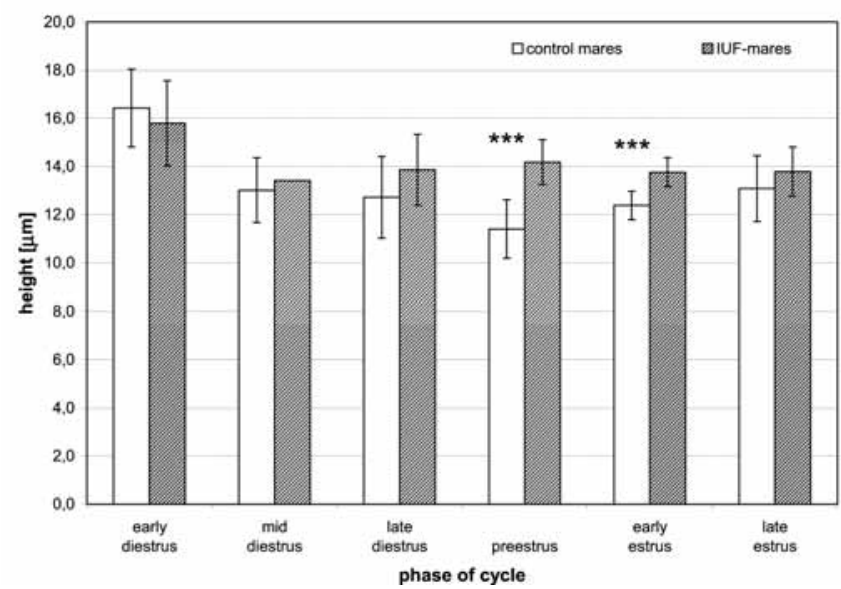

Fig 4 Glandular epithelial height of basal glands in mares with uterine fluid accumulation and control mares during the estrous cycle; values are means $\pm \mathrm{SD}$. Levels of significance: ${ }^{*}=p £ 0.05 ;^{* *}=$ $\mathrm{p} £ 0.01 ;^{* * *}=\mathrm{p} £ 0.001$

\section{Morphometry}

Morphometric measurements of various endometrial structures showed significant differences between the groups only in glandular epithelium. Diameters of glands and glandular lumina in IUF group were greater during all phases of the estrous cycle, especially during estrus ( $P=0.03)$. Mares with uterine fluid accumulation also showed higher values of basal and apical glandular epithelium height during the entire cycle, significantly during proestrus $(P<0.001)$ and early estrus $(P=0.001)$.

\section{Discussion}

Intrauterine fluid occurred dynamically throughout the cycle. Fluid collections are in most cases detected during estrus reaching maximal volumes two days before ovulation. These results are in agreement with previous described about the dynamic nature of uterine fluid collections in mares throughout the cycle (Adams et al. 1987, Allen and Pycock 1988, Kropp 1996).

Ultrasonographically detected fluid accumulations were more often in old barren mares than in young mares. Adams et al. (1987), Carnevale and Ginther (1992) and Kropp (1996) previously mentioned this fact. Supposing that the appearence of IUF is a periodical phenomenon we conclude corresponding to other authers (McKinnon et al. 1987a, Squires 1993, Squires et al. 1989) that it reduces fertility in mares.

IUF mares showed an insufficient progesterone plasma secretion during the luteal phase and exhibited shorter interovulatory intervals. Controversy exists as to whether the CL is malfunctioning or if low concentrations of progesterone are caused by premature luteolysis as a result of endometrial irritants. Ginther et al. (1985) and Adams et al. (1987) describe reduced progesterone concentrations during the luteal phase and reduced length of the interovulatory interval in mares with intrauterine fluid collections. They suggest that both were attributable to uterine inflammation and due to early activation of the uterine luteolytic mechanism by the inflammatory process. Since blood samples for progesterone analysis were not taken before an inflammatory process would be expected to cause luteolysis (before day 5; 10), early activation of luteolysis could not be differentiated from primary luteal inadequacy. In the present study histopathologic examinations did not indicate acute endometritis though microbiology indicated susceptibility to endometritis of IUF mares. Adams et al. (1987) showed that progesterone concentrations rose to normal by day 5 and by day 8 began to decline. Bacterial endometritis, endometritis caused by intrauterine infusion or endometrial biopsy (Hurtgen and Ganjam 1979) can trigger the release of $\mathrm{PGF}_{2 \mathrm{a}}$ form the uterus and result in luteolysis. Manipulation of the genital tract, including palpation and manipulation of the uterus, cervical dilatation (Hurtgen and Ganjam 1979), embryo flushing, and embryo transfer (Betteridge et al. 1985) can induce the release of $\mathrm{PGF}_{2 \mathrm{a}}$ too. Probably manipulation of the uterus in this study had a negative influence on progesterone secretion. On the other hand it has been soon realized that the corpus luteum is not susceptible to $\mathrm{PGF}_{2 \mathrm{a}}$ until day 5 after ovulation, presumably because $\mathrm{PGF}_{2 \mathrm{a}}$ receptors which mediate its action are not 
present earlier (Hafs et al. 1974). In contrast to results of Adams et al. (1987) in the present study progesterone profiles of IUF mares did not rise to normal until day 5, but were below physiologic levels throughout the whole luteal phase and prostaglandin concentrations were not elevated in early luteal phase. This results may indicate primary luteal inadequacy as the reason for lacking progesterone secretion, though this phenomenon has not been well studied in the mare. The luteal phase defect (LPD) in humans is not a unique and independently established clinical entity, but a syndrome characterized by a multifaceted pathogenesis (Mori 1992). The most common cause of LPD in humans is transient hyperprolactinemia. A second cause of LPD is suspected to be disturbed follicle development due to the inappropriate ratio of LH/FSH in the hyper-LH syndrome. Another cause is speculated to be the primary failure of a response from the corpus luteum to LH (Aisaka et al. 1992). Further investigations in the etiology of LPD in mares are necessary.

Morphometry has shown differences in glandular epithelium between the groups during the estrous phase. Kropp (1996) and Rasch (1994) also found larger diameters of glandular lumina and glandular diameters in their study. These differences may be interpreted as an asynchronous to cycle and hypersecretory glandular maldifferentiation. We conclude that the clinical symptomatology of fluid accumulation reflects the morphologic equivalent of glandular maldifferentiation. Cell differentiation is regulated by receptor mediated hormone action.

In the present study the expression of ER, PR and Ki-67 antigen was in some phases of cycle increased in the IUF group. In the mammalian uterus, 17b-estradiol stimulates the synthesis of ER and PR (Fernandes et al. 1989, Johnston et al. 1985, McDowell et al. 1988, Slyden et al.1993) thus increasing receptor availability in cytosol and uterine sensitivity to $E$ and $P$ action. In E-primed uterus, $P$ reduces $P R$ levels and inhibits cytosol ER replenishment (Okulicz 1989, Okulicz et al. 1990, Press et al. 1984). In the mare the steroid receptor concentrations seems to be regulated by progesterone. When progesterone concentration is low, steroid receptor concentrations are high, and when progesterone concentrations increase, receptor concentration tend to decrease (Krüdewagen 1996, Tomanelli et al. 1991). Results of the present study confirm the inverse progesterone-dependent expression of steroid receptors in stromal cells. This correlation may explain the increased receptor expression and as a consequence failure in cell differentiation in IUF mares. Lacking plasma progesterone levels may impede physiologic receptor "down regulation".

In mice estradiol-17b acts through the ER to regulate uterine growth and functional differentiation, but epithelial ER is neither necessary nor sufficient for estradiol-induced uterine epithelial proliferation. Instead, estradiol induction of epithelial proliferation appears to be a paracrine event mediated by ERpositive stroma (Cooke et al. 1997). The same regulatory mechanism might exist in the mare. Increased stromal cell proliferation in IUF mares may then be a direct consequence of elevated receptor concentrations.

The formation of free uterine fluid may be the consequence of luteal insufficiency that results in steroid receptor mediated maldifferentiation of endometrial glandular cells.

\section{Literature}

Adams G.P., J.P. Kastelic, D.R. Bergfelt und O.J. Ginther (1987): Effect of uterine inflammation and ultrasonically-detected uterine pathology on fertility in the mare. J. Reprod. Fertil., Suppl. 35, 445 454

Aisaka K., K. Yoshida und H. Mori (1992): Analysis of clinical bakkgrounds and pathogenesis of luteal-phase defect.Horm. Res. 37, Suppl. 1, $41-47$

Allen W.E. und J.F. Pycock (1988): Cyclical accumulation of uterine fluid in mares with lowered resistance to endometritis. Vet. Rec. $122,489-490$

Behrens C., J.E. Aurich, E. Klug, H. Naumann und H.-O. Hoppen (1993): Inhibition of gonadotrophin release in mares during the luteal phase of the oestrous cycle by endogenous opioids. J. Reprod. Fertil. 98, 509-514

Beglund L.A., D.C. Sharp, M.W. Vernon U. W.W. Thatcher (1982): Effect of pregnancy and collection techniques on prostaglandin $F$ in the uterine lumen of pony mares. J. Reprod. Fertil., Suppl. 32, 335-34 1

Betteridge K.J., A. Renard und A.K. Goff (1985): Uterine prostaglandin release relative to embryo collection, transfer procedure and maintenance of the corpus luteum. Equine vet. J., Suppl. 3, 25-33

Carnevale E.M. und O.J. Ginther (1992): Relationship of age to uterine function and reproduction efficiency in mares. Theriogenology. $37,1101-1115$

Cooke P.S., D.L. Buchanan, P. Young, T. Setiawan, J. Brody, K.S. Korach, J. Taylor, D.B. Lubahn und G.R. Cunha (1997): Stromal estrogen receptors mediate mitogenic effects of estradiol on uterine epithelium. Proc. Natl. Acad. Sci. U.S.A. 94, 6535-6540

Fernandes P.A., R.A. Bowen, H.R. Sawyer, T.M. Nett und T.A. Gorell (1989): Concentration of receptors for estradiol and progesterone in canine endometrium during estrus and diestrus. Am. J. vet. Res. $50,64-67$

Ginther O.J., M.C. Garcia, D.R. Bergfelt, G.S. Leith und S.T. Scraba (1985): Embryonic loss in mares: Pregnancy rate, length of interovulatory intervals and progesterone concentrations associated with loss during days 11 to 15. Theriogenology. 21, 505-516

Hafs H. D., Lovis T.M., Noden P.A. und Oxender W.D. (1985): Control of the estrous cycle with prostaglandin F2a in cattle and horses. J. Anim. Sci., Suppl. 38, 10

Hurtgen J.P. und V.K. Ganjam (1979): The effect of intrauterine and cervical manipulation on the equine oestrous cycle and hormone profiles. J. Reprod. Fertil., Suppl. 27, 191-197

Johnston S.D., D.T. Kiang und B.E. Seguin (1985): Cytoplasmatic estrogen and progesterone receptors in canine endometrium during the estrous cycle. Am. J. vet. Res. 46, 1653-1658

Katila T., T. Reilas, O. Mäkelä, M. Huhtinen und E. Koskinen (1997): Intrauterine fluid accumulation in oestrous mares in: Havemeyer Foundation Int. Workshop on Uterine defense mechanisms in the mare: Aspects of physical clearance., Gainesville 1997, Kongr.ber.

Kenney R.M. und P.A. Doig (1986): Equine endometrial biopsy in: Morrow D.A. (editor): Current therapy in Theriogenology. 2nd edition Verlag W.B. Saunders Company, Philadelphia, Pa., 723-729

Kropp G. (1996): Ätiopathogenetische Faktoren der Hydromukometra sowie Beurteilung des therapeutischen Effektes von Oxytocin bei östrischen Stuten. Vet. Med. Diss. Hannover

Krüdewagen E.M. (1996): Untersuchungen zum Östrogenrezeptornachweis im Pferdeendometrium - Vergleich verschiedener Methoden. Vet. Med. Diss. Hannover

LeBlanc M.M., A.C. Asbury und S.K. Lyle (1989): Uterine clearance mechanisms during the early postovulatory period in mares. Am. J. vet. Res. 50, 864-867

LeBlanc M.M., L. Nneuwirth, L. Jones, C. Cage und D. Mauragis (1998): Differences in uterine position of reproductively normal mares and those with delayed uterine clearance detected by scintigraphy. Theriogenology. 50, 49-54

Liu I.K.M. (1992): The causes and significance of fluid accumulation in the uterus in: Proc. of the John P. Hughes Int. Workshop on equine endometritis, Newmarket 1992, Equine vet. J. 25, 184-193 
McDowell K.J., D.J. Sharp, W. Grubaugh, W.W. Thatcher und C.J. Wilcox (1988): Restricted conceptus mobility results in failure of pregnancy maintenance in mares. Biol. Reprod. 39, 340-348

McKinnon A.O., E.L. Squires, E.M. Carnevale, L.A. Harrison, D.D. Frantz, A.E. McChesney und R.K. Shideler (1987 a): Diagnostic ultrasonography of uterine pathology in the mare. Proc. Annu. Conv. Am. Assoc. Equine Pract. 33, 605-622

McKinnon A.O., E.L. Squires, L.A. Harrison, E.L. Black und R.K. Shideler (1988 b): Ultrasonographic studies on the reproductive tract of mares after parturition: Effect of involution and uterine fluid on pregnancy rates in mares with normal and delayed first postpartum ovulatory cycles. J. Am. Vet. Med. Assoc. 192, 350-353

McKinnon A.O., E.L. Squires und J.L. Voss (1987 b): Ultrasound evaluation of the mare's reproductive tract: Part II. Comp. Contin. Educ. Pract. Vet. 9, 472-482

Merkt H., W. Bisping, A.-R. Günzel und G. Kirpa (1980): Die Tupferprobe in der gynäkologischen Untersuchung der Stute. Prakt. Tierarzt. 61, 301-308

Mori H. (1992): New aspects of the physiology and pathology of the luteal phase: an overview. Horm. Res. 37, Suppl. 1, 3-4

Newcombe J.R. (1997): The effect of the incidence and depth of intra-uterine fluid in early dioestrus on pregnancy rate in mares. Pferdeheilkunde 13, 545

Okulicz W.C. (1989): Temporal effects of progesterone inhibition of occupied nuclear oestrogen receptor retention in the rat uterus. J. Endocrinol. 121, 101-107

Okulicz W.C., A.M. Savasta, L.M. Hoberg und C. Longcope (1990): Biochemical and immunohistochemical analyses of estrogen and progesterone receptors in the rhesus monkey uterus during the proliferative and secretory phases of artificial menstrual cycles. Fertil. Steril. 53, 913-920

Press M.F., N. Nousek-Goebl, W.J. King, A.L. Herbst und G.L. Greene (1984): Immunohistochemical assessment of estrogen receptor distribution in the human endometrium throughout the menstrual cycle. Lab. Invest. 51, 495-503
Pycock J.F. und J.R. Newcombe (1996 b): The relationship between intraluminal uterine fluid, endometritis and pregnancy rate in the mare. Equine Pract. 18, 19-22

Rasch K. (1994): Einfluss von Oxytocin auf den uterinen Efflux und die Fertilität bei östrischen Stuten. Vet. Med. Diss. Hannover

Slaydon O.D., J.J. Hirst und R.M. Brenner (1993): Estrogen action in the reproductive tract of rhesus monkeys during antiprogestin treatment. Endocrinology. 132, 1845-1856

Squires E.L. (1993): Ultrasonography in broodmare practice. Equine Vet. Data. 14, 132-133

Squires E.L., C.K. Barnes, H.S. Rowley, A.O. McKinnon, B.W. Picket und R.K. Shideler (1989): Effect of uterine fluid and volume of extender on fertility. In: Proc. of the 35th Meeting Am. Assoc. Equine Pract., 25-30

Tomanelli R.N., P.L. Sertich und E.D. Watson (1991): Soluble oestrogen and progesterone receptors in the endometrium of the mare.J. Reprod. Fertil., Suppl. 44, 267-273

Troedsson M.H.T. und I.K.M. Liu (1991): Uterine clearance of nonantigenic markers $(51 \mathrm{Cr}$ ) in response to a bacterial challenge in mares potencially susceptible and resistant to chronic uterine infections. J. Reprod. Fertil., Suppl. 44, 283-288

Troedsson M.H.T., A.O.G. Wiström, I.K.M. Liu, M. Ing, J. Pascoe und M. Thurmond (1993): Registration of myometrial activity using multiple site electromyography in cyclic mares. J. Reprod. Fertil. 99, 299-306

Dr. Sibel Özgen

Klinik für Pferde

School of Veterinary Medicine Hannover

Bischofsholer Damm 15

D-30173 Hannover

FAX: +49-51 1-856-7681 